\title{
Insulin-like Growth Factor-I Enhances Luteinizing Hormone Binding to Rat Ovarian Theca-interstitial Cells
}

\author{
José F. Cara, Jiong Fan, Jayne Azzarello, and Robert L. Rosenfield \\ Department of Pediatrics, The University of Chicago Pritzker School of Medicine, Section of Pediatric Endocrinology, \\ Wyler Children's Hospital, Chicago, Illinois 60637
}

\begin{abstract}
We tested the hypothesis that insulin-like growth factor-I (IGF-I) stimulates ovarian androgen production by increasing theca-interstitial cell luteinizing hormone (LH) binding affinity and/or binding capacity. We then investigated the role of transcriptional and translational events in mediating these actions of IGF-I.

LH bound to saturable, high affinity binding sites on rat ovarian theca-interstitial cells. Preincubation with LH produced a decrease in LH binding capacity with no effect on LH binding affinity. Treatment with IGF-I, both in the absence and presence of $\mathrm{LH}$, increased $\mathrm{LH}$ binding capacity 1.5 - to 2-fold with no change in LH binding affinity. Androgen production was increased progressively by LH, suggesting that LH-stimulated steroidogenesis is not tightly coupled to $\mathrm{LH}$ receptor downregulation. IGF-I increased androgen synthesis in proportion to its upregulation of $\mathrm{LH}$ binding capacity. Transcriptional inhibition with dichlorobenzimidazole riboside inhibited the IGF-I-mediated increase in LH binding capacity but had no effect on androgen production. Translational inhibition with cycloheximide inhibited both the IGF-I-mediated increase in LH binding and stimulation of androgen synthesis.

We conclude that IGF-I increases theca-interstitial cell LH binding capacity and reverses the LH-induced downregulation of LH binding sites. The enhancement of LH binding by IGF-I is compatible with transcriptional mediation whereas the effect of IGF-I on androgen synthesis appears to be mediated by a direct effect of the peptide on the translational process(es) involved in steroidogenesis. (J. Clin. Invest. 1990. 86:560565.) Key words: insulin-like growth factor-I • luteinizing hormone $\bullet$ androgen $\bullet$ theca
\end{abstract}

\section{Introduction}

Insulin-like growth factor-I (IGF-I) ${ }^{1}$, together with insulin and insulin-like growth factor-II, forms part of a family of serum peptides with potent metabolic and mitogenic activities $(1,2)$. The binding of IGF-I to its cell surface receptor stimu-

Presented in part at the 71 st Annual Meeting of the Endocrine Society, 22 June 1989, Seattle, WA.

Address correspondence to Dr. José F. Cara, Wyler Children's Hospital, Box 118, 5841 South Maryland Avenue, Chicago, IL 60637.

Received for publication 17 April 1989 and in revised form 27 March 1990.

1. Abbreviations used in this paper: $\mathrm{CHX}$, cycloheximide; DRB, dichlorobenzimidazole; hCG, human chorionic gonadotropin; IGF-I, insulin-like growth factor-I.

J. Clin. Invest.

(c) The American Society for Clinical Investigation, Inc. 0021-9738/90/08/0560/06 $\$ 2.00$

Volume 86, August 1990, 560-565 lates DNA synthesis and cellular differentiation in a variety of tissues (2). Recent studies suggest that IGF-I plays a role in ovarian theca-interstitial cell function (3-5). These cells, under stimulation by luteinizing hormone (LH), are responsible for the synthesis of the androgenic precursors required for estrogen production by the ovary $(6,7)$. Studies using primary cultures of rat ovarian theca-interstitial cells indicate that these cells contain IGF-I receptors and respond to IGF-I with an increase in androgen synthesis; treatment with IGF-I in concentrations of $1-100 \mathrm{ng} / \mathrm{ml}$ potentiates the $\mathrm{LH}$-induced stimulation of androgen output 5- to 30-fold above levels seen with LH alone (3-5). Insulin, by interacting with its own or IGF-I receptors, can mimic the effects of IGF-I on the ovary, stimulating androgen production to values observed with IGF-I (3, 5, 8-11).

These studies have provided insight into the role of IGF-I and insulin in the pathophysiology of polycystic ovary syndrome, a clinical condition characterized by theca-interstitial cell hyperplasia, hyperandrogenism, and virilization (12). Polycystic ovary syndrome has been described in acromegaly and is frequently encountered in insulin resistant syndromes that are accompanied by hyperinsulinemia $(10,12-15)$. It appears likely that in these conditions the elevated IGF-I or insulin concentrations are interacting with IGF-I receptors and stimulating theca-interstitial cell hyperplasia and increased androgen production $(10,12,15)$.

The mechanisms by which IGF-I potentiates the LH-induced stimulation of androgen synthesis are not clear. In the present study, we tested the hypothesis that IGF-I increases androgen synthesis in rat ovarian theca-interstitial cells by increasing $\mathrm{LH}$ receptor number and/or binding affinity. Having observed this to be the case, we then investigated the role of transcriptional and translational events in mediating the effects of IGF-I on androgen synthesis and LH binding.

\section{Methods}

Reagents. The highly purified human LH I-3 was kindly provided by Dr. A. F. Parlow, distributed through the National Hormone and Pituitary Program and National Institutes of Health; and biosynthetic IGF-I ${ }^{\text {Thr59 }}$ was obtained from Amgen Biologicals (Thousand Oaks, CA). Immature, hypophysectomized female Sprague-Dawley rats were obtained from Hormone Assay Laboratories (Chicago, IL). Deoxyribonuclease, medium 199 (with Hanks' salts, $100 \mathrm{mg} /$ liter L-glutamine, and $25 \mathrm{mM}$ 4-(2-hydroxyethyl)-1-piperazine-ethanesulfonic acid), McCoy's 5A medium, penicillin-streptomycin solution, L-glutamine, and trypan blue stain were obtained from Grand Island Biological Co. (Grand Island, NY). Dichlorobenzimidazole riboside (DRB) and cycloheximide (CHX) were obtained from Sigma Chemical Co. (St. Louis, MO). Collagenase was obtained from Cooper Biomedical Inc. (Chester, PA) and chromatography supplies were obtained from BioRad Laboratories (Richmond, CA).

Cell dispersal and culture. Theca-interstitial cells were obtained from hypophysectomized rats following the procedure described by 
Magoffin and Erickson (6). Briefly, ovaries from 20-d-old hypophysectomized female Sprague-Dawley rats were removed on the fourth postoperative day, minced, and theca-interstitial cells dispersed with collagenase and deoxyribonuclease as described previously $(3,6)$. Approximately 1-2 $11^{6}$ cells were obtained from each ovary and $90 \%$ were determined to be viable by trypan blue dye exclusion. The dispersed cells were cultured on 6-well plates at a concentration of $\sim 1$ $\times 10^{6}$ cells $/ \mathrm{ml}$ in serum-free McCoy's medium supplemented with 100 $\mathrm{U} / \mathrm{ml}$ penicillin, $100 \mu \mathrm{g} / \mathrm{ml}$ streptomycin, and $2 \mathrm{mM} \mathrm{L-glutamine}$ in $5 \% \mathrm{CO}_{2}$ at $37^{\circ} \mathrm{C}$. Dispersed cells in triplicate wells were preincubated with and without the desired hormones by culturing for $48 \mathrm{~h}$ in serum-free medium in the absence (control) and in the presence of increasing concentrations of LH and/or IGF-I. Binding studies were performed after $48 \mathrm{~h}$ of preincubation, once the cells had become adherent to the polystyrene plates. In all cases, the medium was removed before performing the binding assays and stored at $-20^{\circ} \mathrm{C}$ until assayed for steroids. In all experiments an aliquot of the cellular material was saved for determination of the DNA concentration, as described previously (3).

Androsterone assay. The supernatant medium from theca-interstitial cells preincubated with the desired hormones and/or inhibitors, as described above, was removed and stored at $-20^{\circ} \mathrm{C}$ until assayed for steroids. The androsterone concentration in these samples was quantitated by RIA after benzene extraction, as described previously (3).

Radiolabeling of $\mathrm{LH}$. LH was radiolabeled to a specific activity of $\sim 100-200 \mu \mathrm{Ci} / \mu \mathrm{g}$ as described previously (16). Briefly, highly purified LH I-3 was radioiodinated with ${ }^{125}$ I using the chloramine T technique (17) and the radioactive protein fraction separated from inorganic iodide on a $0.9 \times 10 \mathrm{~cm}$ Sephadex G-50 column (Pharmacia Fine Chemicals, Piscataway, NJ). The radiolabeled proteins were further chromatographed on a $1.5 \times 90 \mathrm{~cm}$ column of Sephadex G-100. The column was developed with a buffer composed of $0.05 \mathrm{M} \mathrm{NaH}_{2} \mathrm{PO}_{4}$, $0.15 \mathrm{M} \mathrm{NaCl} \mathrm{pH} 7.4$ at a flow rate of $\sim 20 \mathrm{ml} / \mathrm{h}$. The fractions in the radioactive peak corresponding to the highest LH biopotency were pooled and used for binding studies.

LH binding studies. LH binding studies were performed as described by Magoffin and Erickson (6), with modifications. Briefly, monolayer cultures of ovarian theca-interstitial cells preincubated with and without added hormones were washed with medium 199 containing $0.1 \% \mathrm{BSA}$ and incubated in the same medium with $\sim 10 \mathrm{pM}$ radiolabeled $\mathrm{LH}$ in the presence and absence of increasing concentrations of unlabeled hormone. After incubation, the cells were washed with ice-cold PBS, solubilized with $0.5 \mathrm{~N} \mathrm{NaOH}$, and an aliquot removed for determination of the bound radioactivity. Total binding was defined as the radioactivity bound to monolayers in the absence of unlabeled LH. Nonspecific binding was determined by measuring the bound radioactivity in the presence of $1 \mu \mathrm{g} / \mathrm{ml}$ unlabeled $\mathrm{LH}$.

Competitive binding data were analyzed as described previously (3) by a modification of the method of Marquardt (18) and by the method of Scatchard (19) to determine the dissociation constant and the binding capacity. For these calculations, it is assumed that the LH preparation is pure and has full biological activity (i.e., $1 \mathrm{nmol} \mathrm{LH}$ equals $\sim 28.5 \mu \mathrm{g}$ ).

Cell culture with transcriptional and translational inhibitors. DRB, a specific inhibitor of RNA polymerase II (20), and CHX, an inhibitor of protein synthesis (21), were used to examine the role of transcriptional and translational events, respectively, in mediating the actions of IGF-I on androsterone synthesis and LH binding. Briefly, theca-interstitial cells were plated onto multiwell plates in serum free medium without added hormones or inhibitors. After $24 \mathrm{~h}$, increasing concentrations of hormones and inhibitors were added to the cells. After incubating for $6 \mathrm{~h}$ (in the case of DRB) or $4 \mathrm{~h}$ (in the case of $\mathrm{CHX}$ ) the medium was replaced with fresh medium containing the desired concentrations of hormones but without added inhibitors. After incubating the cells for an additional $18 \mathrm{~h}$ (in the case of DRB) or $20 \mathrm{~h}$ (in the case of $\mathrm{CHX}$ ), the medium was removed and saved for steroid determinations and LH binding studies were performed, as described above.

Analysis of data. Data were analyzed by Student's one-tailed paired $t$ test. All data are expressed as mean \pm SEM, unless otherwise noted.

\section{Results}

LH binding to theca-interstitial cell monolayers was time and temperature dependent. Maximal binding was observed after incubating for $24 \mathrm{~h}$ at $23^{\circ} \mathrm{C}$ (data not shown). Consequently, all binding studies were performed under these conditions.

LH bound to a single class of saturable, high affinity binding sites on rat ovarian theca-interstitial cells. In cells cultured in serum free medium without added hormones (control), half-maximal inhibition of radiolabeled LH binding by unlabeled hormone was observed with an $\mathrm{LH}$ concentration of $\sim 0.1 \mathrm{nM}$, as shown in Fig. 1. Analysis of the binding data from four separate determinations by a modification of the method of Marquardt (18) revealed a single class of binding sites with a $K_{\mathrm{d}}$ of $\sim 0.05 \pm 0.01 \mathrm{nM}$. The binding capacity, as determined from four separate determinations by the method of Scatchard (19), was $\sim 1.9 \pm 0.25 \mathrm{fmol} / 10^{6}$ cells. Taking into account the percentage of theca-interstitial cells present in this primary culture system (7), these results suggest that the number of LH binding sites on theca-interstitial cells approximates 3,500 sites/cell. These figures must be considered approximations of the binding characteristics of theca-interstitial cell $\mathrm{LH}$ receptors because of possible variations in purification and glycosylation of the LH standards used in such experiments $(16,22)$.

LH was found to decrease the number of specific binding sites for LH in cultured theca-interstitial cells. As shown in Fig. 2 , monolayers preincubated for $48 \mathrm{~h}$ with $1(\sim 0.04 \mathrm{nM})$ and $10 \mathrm{ng} / \mathrm{ml}(\sim 0.4 \mathrm{nM}) \mathrm{LH}$ showed a decrease in the maximal specific radiolabeled $\mathrm{LH}$ bound to $69 \pm 15 \%$ and $6 \pm 1 \%$ ( $P$ $<0.01)$ of control, respectively. Similar results were obtained when binding studies were performed after washing the monolayers and placing them in serum free medium for $24 \mathrm{~h}$ before performing the binding studies (data not shown). To determine if the decrease in LH binding was the result of a decrease in the binding affinity, binding capacity, or both, competitive binding studies were performed after cell monolayers had been

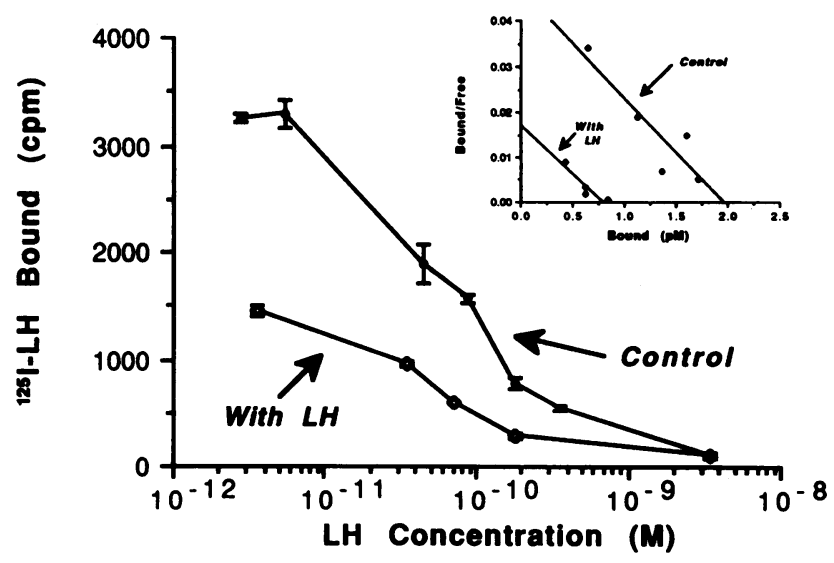

Figure 1. Binding of LH to rat ovarian theca-interstitial cells and effect of preincubation of theca-interstitial cells with LH on subsequent radiolabeled LH binding. The competitive binding curves show radiolabeled LH binding to cell monolayers preincubated for $48 \mathrm{~h}$ without added hormones (Control) and with $\mathrm{LH}(1 \mathrm{ng} / \mathrm{ml})$ prior to performing the binding experiments. Shown is the mean \pm SD for triplicate samples from a representative experiment. Similar results were obtained from three additional determinations. (Inset) Scatchard analysis of binding data from competitive binding experiments showing LH induced downregulation of LH binding sites. 


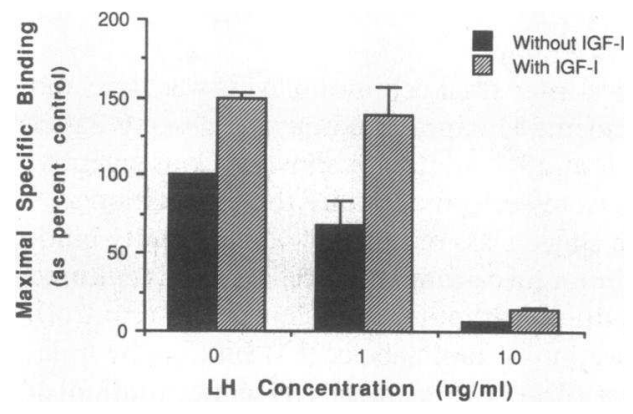

Figure 2. Percent maximal specific LH binding to theca-interstitial cell monolayers preincubated with increasing concentrations of $\mathrm{LH}$ alone and in combination with IGF-I $(100 \mathrm{ng} / \mathrm{ml})$. Shown is the percent maximal specific radiolabeled LH binding compared to control (cells cultured without LH and without IGF-I). Results shown are the mean \pm SEM from four separate determinations.

preincubated for $48 \mathrm{~h}$ in the presence of 1 or $10 \mathrm{ng} / \mathrm{ml} \mathrm{LH}$. Analysis of the binding data from cells preincubated with 1 $\mathrm{ng} / \mathrm{ml} \mathrm{LH}$ revealed a decrease in the binding capacity with no change in the $K_{\mathrm{d}}$, as shown in Fig. 1 (inset) and in Table I. The binding of radiolabeled $\mathrm{LH}$ after preincubation with $10 \mathrm{ng} / \mathrm{ml}$ LH was too low to allow appropriate analysis of the competitive binding data.

When rat ovarian theca-interstitial cells were preincubated with IGF-I, an increase in radiolabeled LH binding was observed. Increasing concentrations of IGF-I progressively increased radiolabeled LH binding to theca-interstitial cells; 1 , 10 , and $100 \mathrm{ng} / \mathrm{ml} \mathrm{IGF-I} \mathrm{increased} \mathrm{the} \mathrm{percent} \mathrm{maximal} \mathrm{LH}$ bound to 121,144 , and $191 \%$ of control values, respectively. Because $100 \mathrm{ng} / \mathrm{ml}$ IGF-I increased LH binding maximally, while remaining within the physiological range, this dose of IGF-I was selected for further studies. As shown in Fig. 2, preincubation with $100 \mathrm{ng} / \mathrm{ml}$ IGF-I increased the maximal specific binding of $\mathrm{LH}$, both in cells cultured in the absence and presence of either 1 or $10 \mathrm{ng} / \mathrm{ml} \mathrm{LH}$. As can be seen in Fig. 3 , theca-interstitial cells cultured with $100 \mathrm{ng} / \mathrm{ml}$ IGF-I bound more radiolabeled LH than control cells. Scatchard analysis of the binding data revealed that preincubation with IGF-I caused a nearly twofold increase in the LH binding capacity, as shown in Fig. 3 (inset) and in Table I. Likewise, competitive binding studies performed with theca-interstitial cell monolayers preincubated with $\mathrm{LH}$ alone $(1 \mathrm{ng} / \mathrm{ml})$ or a combination of $\mathrm{LH}$ and $100 \mathrm{ng} / \mathrm{ml}$ IGF-I, revealed that cells cultured with a combination of LH and IGF-I bound more radiolabeled LH than cells cultured with LH alone (Fig. 4). Scatchard analysis

Table I. Binding Capacities (fmol $/ 10^{6}$ cells) of Thecainterstitial Cells Preincubated for $48 h$ without Added Hormones and with $\mathrm{LH}(\mathrm{I} \mathrm{ng} / \mathrm{ml})$ and/or IGF-I $(100 \mathrm{ng} / \mathrm{ml})$.

\begin{tabular}{lll}
\hline & Without IGF-I & With IGF-I \\
\hline Without LH & $1.9 \pm 0.25$ & $3.3 \pm 0.05^{*}$ \\
With LH & $1.0 \pm 0.13^{*}$ & $1.9 \pm 0.20^{\ddagger}$ \\
\hline
\end{tabular}

Incubations and binding studies were performed as described in methods. Shown are the mean \pm SEM from four separate determinations.

${ }^{*} P<0.05$ vs. without $\mathrm{LH}$ and IGF-I.

${ }^{\ddagger} P<0.05$ vs. with LH alone.

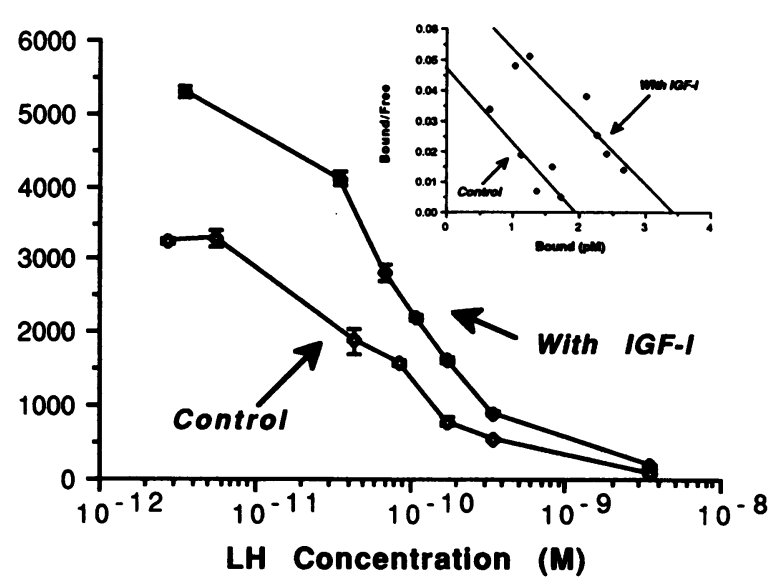

Figure 3. Effect of preincubation of theca-interstitial cells with 100 $\mathrm{ng} / \mathrm{ml}$ IGF-I on subsequent radiolabeled LH binding. Shown are competitive binding curves for cell monolayers cultured in the absence of added hormones (Control) and in the presence of $100 \mathrm{ng} / \mathrm{ml}$ IGF-I. Shown is the mean \pm SD of triplicate samples from a representative experiment. Similar results were obtained from three additional determinations. (Inset) Scatchard analysis of competitive binding data showing that IGF-I increases the LH binding capacity in cultured theca-interstitial cells.

of binding data revealed approximately a twofold increase in the number of high affinity binding sites with no change in the apparent binding affinity, as shown in Fig. 4 (inset) and in Table I.

Androsterone levels were quantitated by RIA in the supernatant medium of theca-interstitial cells in order to determine if the change in $\mathrm{LH}$ binding in response to treatment with $\mathrm{LH}$ (downregulation) or IGF-I (upregulation) was associated with a comparable change in androgen production. As seen in Fig. 5 , incubation of theca-interstitial cells with $1 \mathrm{ng} / \mathrm{ml} \mathrm{LH}$ increased androsterone concentrations nearly fourfold above control values $(117 \pm 17$ vs. $31 \pm 6.5 \mathrm{ng} / \mathrm{ml}$, respectively, $P$

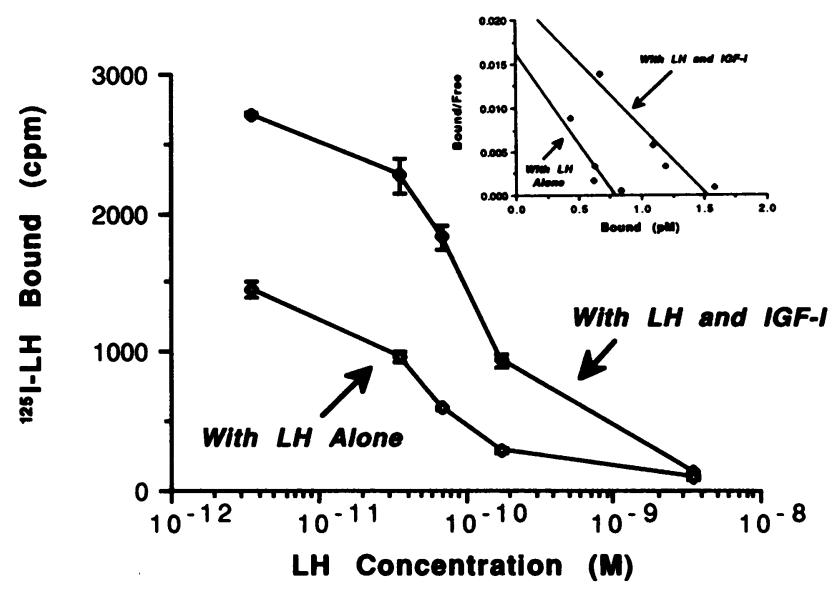

Figure 4. Effect of preincubation of theca-interstitial cells with $\mathrm{LH}$ alone and in combination with IGF-I on subsequent radiolabeled LH binding. Shown are competitive binding curves for cells preincubated for $48 \mathrm{~h}$ with $\mathrm{LH}$ alone $(1 \mathrm{ng} / \mathrm{ml})$ or a combination of LH and IGF-I $(100 \mathrm{ng} / \mathrm{ml})$. Shown is the mean \pm SD of triplicate samples from a representative experiment. Similar results were obtained from three additional determinations. (Inset) Scatchard analysis of competitive binding data showing that IGF-I increases the LH binding capacity in the presence of $\mathrm{LH}$. 


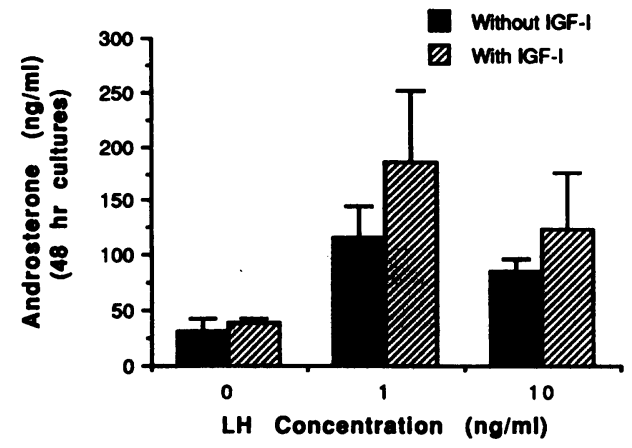

Figure 5. Effect of incubation of theca-interstitial cells with increasing doses of LH, with (hatched bars) and without (black bars) 100 $\mathrm{ng} / \mathrm{ml}$ IGF-I, on androsterone production. Cells were cultured in the absence and presence of LH and/or IGF-I as described in the text. After $48 \mathrm{~h}$, the medium was removed and the androsterone concentration determined by RIA. Shown are mean \pm SEM from three separate determinations.

$<0.05)$. On the other hand, androsterone synthesis by thecainterstitial cells cultured with $10 \mathrm{ng} / \mathrm{ml} \mathrm{LH}$ were lower than those observed with $1 \mathrm{ng} / \mathrm{ml} \mathrm{LH}(86 \pm 6.5 \mathrm{vs} .117 \pm 17 \mathrm{ng} / \mathrm{ml}$, respectively). Incubation of cells with $100 \mathrm{ng} / \mathrm{ml} \mathrm{IGF-I,} \mathrm{in} \mathrm{the}$ presence of both 1 and $10 \mathrm{ng} / \mathrm{ml} \mathrm{LH}$, increased androsterone levels to $186 \pm 39$ and $124 \pm 31 \mathrm{ng} / \mathrm{ml}$, respectively, 59 and $44 \%$ above values obtained with the corresponding doses of LH alone. Thus, the increase in androsterone production induced by IGF-I appeared to be proportional to the upregulation of LH binding capacity stimulated by this peptide.

The effect of DRB and CHX on IGF-I-mediated theca-interstitial cell LH binding capacity and androsterone synthesis were examined in order to determine if the enhancement of LH binding and the increase in androgen production stimulated by IGF-I were mediated by transcriptional and/or translational events. In experiments similar to those described above theca-interstitial cells were preincubated with $100 \mathrm{ng} / \mathrm{ml}$ IGF-I with increasing concentrations of DRB or CHX and LH binding and androsterone production subsequently determined. As shown in Fig. 6, 50 and $100 \mu \mathrm{M}$ DRB inhibited the

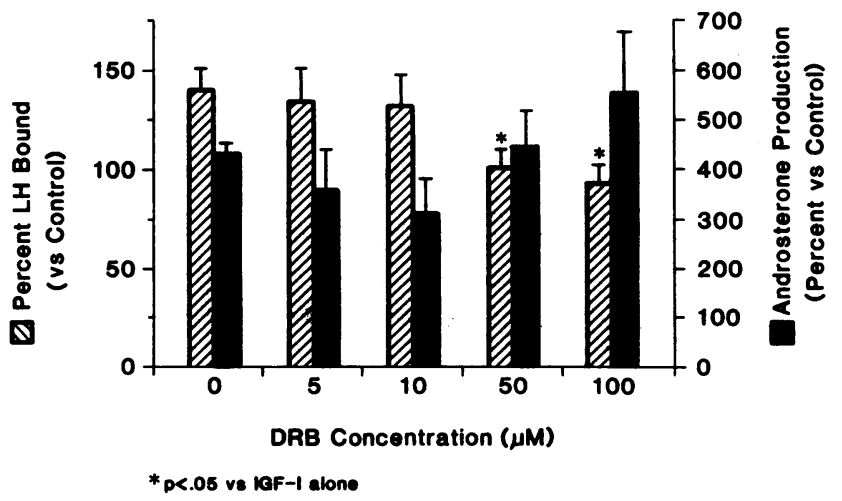

Figure 6. Effect of DRB on IGF-I-mediated enhancement of LH binding and androsterone production in theca-interstitial cell cultures. Theca-interstitial cells were preincubated for $24 \mathrm{~h}$ with 100 $\mathrm{ng} / \mathrm{ml}$ IGF-I, in combination with increasing concentrations of DRB, as described in the text. The medium was subsequently removed, the androsterone concentration quantitated by RIA, and LH binding studies then performed. Shown is the mean \pm SEM percent versus control from three separate determinations. enhancement of LH binding mediated by IGF-I. However, the stimulation of androsterone synthesis under these conditions was not affected. On the other hand, treatment with increasing concentrations of $\mathrm{CHX}$ inhibited both the enhancement of $\mathrm{LH}$ binding and the stimulation of androsterone synthesis mediated by IGF-I, as shown in Fig. 7. At all doses tested, CHX decreased the maximal specific LH binding and stimulation of androsterone synthesis induced by IGF-I to control values. These observations could not be attributed to a difference in cell survival or cell number, since DNA measurements were no different with these various treatments (data not shown).

\section{Discussion}

Recent reports have indicated that the ovarian androgen producing cell represents a target for the actions of IGF-I (3-5). In cultured rat ovarian theca-interstitial cells, IGF-I potentiates the LH-induced stimulation of androgen synthesis in a potent and dose-dependent manner, an effect which becomes signifcant at $96 \mathrm{~h}$ of culture (3). In the present report, we present data supporting the concept that the potentiation of androgen synthesis by IGF-I occurs, at least in part, as the result of an induction of $\mathrm{LH}$ receptors on these cells.

We observed that radiolabeled LH bound to a saturable, high affinity specific binding site on theca-interstitial cells with a binding affinity of $0.05 \mathrm{nM}$ and a binding capacity of $\sim 1.9$ fmol $/ 10^{6}$ cultured cells. Similar results have been reported previously by Magoffin and Erickson (6) and Erickson et al. (7). The possibility that LH bound to the granulosa cells present in the rat ovarian cell monolayers appears unlikely since granulosa cells from hypophysectomized rats lack LH receptors unless stimulated with follicle-stimulating hormone (FSH) $(23,24)$. Likewise, since both our results and results from comparable studies $(3,4)$ have shown that treatment with LH or IGF-I does not lead to an increase in the DNA content of the theca-interstitial-cell monolayers, it is unlikely that the results obtained reflect changes in cell survival or number rather than changes in $\mathrm{LH}$ binding sites.

Preincubation with LH produced a dose-dependent decrease in the LH binding capacity of rat ovarian theca-interstitial cells, suggesting that $\mathrm{LH}$ treatment produces downregula-

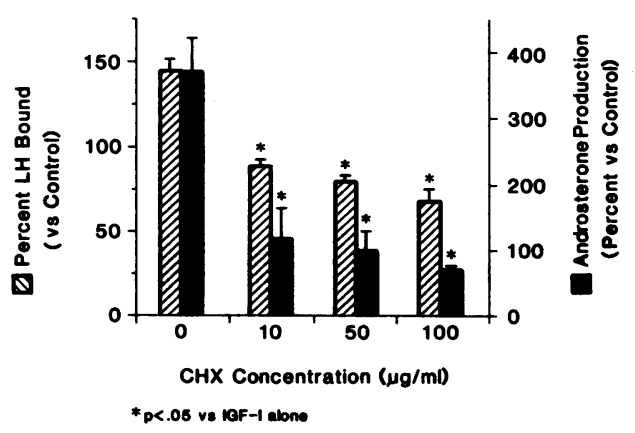

Figure 7. Effect of CHX on IGF-I-mediated enhancement of LH binding and androsterone production in theca-interstitial cell cultures. Theca-interstitial cells were preincubated for $24 \mathrm{~h}$ with 100 $\mathrm{ng} / \mathrm{ml}$ IGF-I, in combination with increasing concentrations of $\mathrm{CHX}$, as described in the text. The medium was subsequently removed, the androsterone concentration quantitated by RIA, and LH binding studies then performed. Shown is the mean \pm SEM percent versus control from three separate determinations. 
tion of LH binding sites in ovarian androgen-producing cells. While this is the first report of down-regulation of LH binding in cultured rat ovarian theca-interstitial cells, our results are consistent with those of other investigators. Bogovich, Richards, and Reichert (25) reported that small increases in LH can increase $\mathrm{LH}$ receptors in theca cells of preovulatory follicles while others $(26,27)$ have reported that higher LH levels, such as seen during the $\mathrm{LH}$ surge, act to decrease the number of $\mathrm{LH}$ receptors and decrease androgen biosynthesis. Similarly, Dufau et al. (28) have shown that the number of $\mathrm{LH}$ receptor sites in testicular Leydig cells, the homologue of ovarian theca-interstitial cells, is also biphasically regulated by $\mathrm{LH}$ or human chorionic gonadotropin (hCG) exposure of Leydig cells to LH or hCG both in vivo and in vitro initially produces a rise in $\mathrm{LH}$ receptor content and androgen secretion whereas prolonged or greater LH or hCG stimulation is followed by a marked and more sustained downregulation of LH binding sites and steroidogenesis. Because of the incubation times used in our experiments, it is not possible to determine whether $\mathrm{LH}$ treatment produced a transient increase in LH binding capacity. Regardless, these results, taken together, suggest that similar mechanisms may be responsible for the control of both testicular and ovarian androgen production by $\mathrm{LH}$.

We also found that IGF-I enhances LH binding to thecainterstitial cells by increasing the LH binding capacity of these cells. Preincubation with IGF-I led to nearly double the binding capacity in cultured theca-interstitial cells (from 1.9 to 3.3 fmol $/ 10^{6}$ cells). In addition, we observed that IGF-I hindered LH-induced downregulation of LH binding sites: preincubation with IGF-I produced a $50-60 \%$ increase in radiolabeled LH binding to cells preincubated with LH. Since the percent reduction in LH binding capacity was the same with and without IGF-I, our data suggest that IGF-I acts by inducing $\mathrm{LH}$ receptor sites rather than by interfering with $\mathrm{LH}$-induced downregulation of $\mathrm{LH}$ binding.

Several growth factors have been reported to increase the number of LH receptors in gonadal tissues. Bernier et al. (29) observed that IGF-I and insulin increase LH binding capacity in testicular Leydig cells while Mondshein and Schomberg (30) found enhanced induction of $\mathrm{LH}$ receptors in granulosa cells by platelet-derived growth factor and other serum peptides. Recently, Adashi et al. reported that IGF-I potentiates the FSH-induced stimulation of hCG binding to rat ovarian granulosa cells (24). These findings, together with those presented in this report, suggest that the enhanced induction of $\mathrm{LH}$ receptors may represent a common mechanism by which gonadal $\mathrm{LH}$ responsiveness is modulated.

We observed that both 1 and $10 \mathrm{ng} / \mathrm{ml} \mathrm{LH}$, while decreasing LH binding capacity to 69 and $6 \%$ of control, respectively, stimulated androsterone synthesis above control values. Androsterone synthesis tended to be lower with the higher dose of LH tested but androsterone production was not as impaired as LH binding in response to this higher dose of LH. This suggests that in thecal cells, as in Leydig cells, LH-induced LH receptor downregulation and androgen synthesis may be dissociated and are mediated by different mechanisms: studies performed in testicular Leydig cells have shown that LH-induced $\mathrm{LH}$ receptor loss can be uncoupled from changes in testosterone secretion at intermediate LH doses (31). In Leydig cells, prolonged exposure to higher concentrations of LH results in impaired androgen production and is probably the case in theca too, as a result of a decrease in the activity of stromal steroidogenic enzymes, as reviewed by Richards and Hedin (27).

We observed that treatment with both DRB and CHX inhibited the effect of IGF-I on the enhancement of LH binding. Thus, inhibition of both transcription and translation, respectively, inhibited the IGF-I-induced increase in LH binding capacity. These results suggest that the increase in LH binding capacity stimulated by IGF-I is mediated by transcriptional events, possibly the result of a direct effect of IGF-I on LH receptor gene expression or, alternatively, the result of an effect of IGF-I on the expression of regulatory proteins affecting LH binding capacity. On the other hand, inhibition of transcription had no effect on the increase in androsterone production stimulated by IGF-I while translational inhibition blunted this biological response. These results suggest that the effects of IGF-I on androgen production by theca-interstitial cells are in part mediated by a direct effect of this peptide on the translational processes required for androgen biosynthesis. This effect of IGF-I could involve synthesis of either the steroidogenic enzymes or the synthesis of regulatory proteins that modulate steroidogenic enzyme activity.

\section{Acknowledgments}

This work was supported in part by the University of Chicago Louis Block Fund, an American Diabetes Association Young Investigator Research Award, and U. S. Public Health Service grants DK 20595, HD 06308, and RR 55.

\section{References}

1. Daughaday, W. H., K. Hall, W. D. Salmon, J. L. Van Den Brande, and J. J. Van Wyk. 1987. On the nomenclature of the somatomedins and insulin-like growth factors. J. Clin. Endocrinol. \& Metab. 65:1075-1076.

2. Froesch, E. R., C. Scmid, J. Schwander, and J. Zapf. 1985. Actions of insulin-like growth factors. Annu. Rev. Physiol. 47:443-467.

3. Cara, J. F., and R. L. Rosenfield. 1988. Insulin-like growth factor- 1 and insulin potentiate luteinizing hormone-induced androgen synthesis by rat ovarian theca-interstitial cells. Endocrinology. 123:733-739.

4. Hernandez, E. R., C. E. Resnick, M. E. Svoboda, J. J. Van Wyk, D. W. Payne, and E. Y. Adashi. 1988. Somatomedin-C/Insulin-like growth factor $I$ as an enhancer of androgen biosynthesis by cultured rat ovarian cells. Endocrinology. 122:1603-1612.

5. Magoffin, D. A., and G. F. Erickson. 1988. An improved method for primary culture of ovarian androgen-producing cells in serum free medium: effect of lipoproteins, insulin, and insulin-like growth factorI. In. Vitro Cell. \& Dev. Biol. 24:862-870.

6. Magoffin, D. A., and G. F. Erickson. 1982. Primary culture of differentiating ovarian androgen producing cells in defined medium. $J$. Biol. Chem. 257:4507-4513.

7. Erickson, G. F., D. A. Magoffin, C. A. Dyer, and C. Hofeditz. 1985. The ovarian androgen producing cells: a review of structure/ function relationships. Endocr. Rev. 6:371-399.

8. Hill, D. J., and R. D. G. Milner. 1985. Insulin as a growth factor. Pediatr. Res. 19:879-886.

9. Barbieri, R. L., A. Makris, and K. J. Ryan. 1984. Insulin stimulates androgen accumulation in incubations of human ovarian stroma and theca. Obstet. Gynecol. 64(suppl.):73s-80s.

10. Poretsky, L., and M. F. Kalin. 1987. The gonadotropic function of insulin. Endocr. Rev. 8:132-141.

11. Hernandez, E. R., C. E. Resnick, W. D. Holztclaw, D. W. Payne, and E. Y. Adashi. 1988. Insulin as a regulator of androgen 
biosynthesis by cultured rat ovarian cells: cellular mechanism(s) underlying physiological and pharmacological hormonal actions. Endocrinology. 122:2034.

12. Barnes, R., and R. L. Rosenfield. 1989. The polycystic ovary syndrome: pathogenesis and treatment. Ann. Intern. Med. 110:386399.

13. Stuart, C. A., M. J. Prince, E. J. Peters, and W. J. Meyer III. 1987. Hyperinsulinemia and hyperandrogenemia: in vivo androgen response to insulin infusion. Obstet. Gynecol. 69:921-925.

14. Urdl, W. 1988. Polycystic ovarian disease: endocrinological parameters with specific reference to growth hormone and somatomedin-C. Arch. Gynecol. Obstet. 243:13-36.

15. Taylor, S. I. 1987. Insulin action and inaction. Clin. Res. 35:459-472.

16. Burstein, S., E. Schaff-Blass, J. Blass, and R. L. Rosenfield. 1985. The changing ratio of bioactive to immunoreactive luteinizing hormone (LH) through puberty principally reflects changing, $\mathrm{LH}$ radioimmunoassay dose-response characteristics. J. Clin. Endocrinol. \& Metab. 61:508-513.

17. Greenwood, F. C., W. M. Hunter, and J. S. Glover. 1963. The preparation of ${ }^{131} \mathrm{I}$-labeled human growth hormone of high specific radioactivity. Biochem. J. 89:114-123.

18. Yamaoka, K., Y. Tanigawara, T. Nakagawa, and T. Uno. 1981. A pharmacokinetic analysis program (MULTI) for microcomputer. $J$. Pharmacobio-Dyn. 4:879-885.

19. Scatchard, G. 1949. The attractions of proteins for small molecules and ions. Ann. NY Acad. Sci. 51:660-672.

20. Chodosh, L. A., A. Fire, M. Samuels, and P. A. Sharp. 1989. 5,6-dichloro-1- $\beta$-D-ribofuranosylbenzimidazole inhibits transcription elongation by RNA polymerase II in vitro. J. Biol. Chem. 264:22502257.

21. Pestka, S. 1971. Inhibitors of ribosome function. Annu. Rev. Microbiol. 25:487-562.

22. Robertson, D. M., and E. Diczfalusy. 1977. Biological and immunological characterization of human luteinizing hormone. II. A comparison of the immunological and biological activities of pituitary extracts after electrofocusing using different standard preparations. Mol. Cell. Endocrinol. 9:57-67.

23. Erickson, G. F., C. Wang, and A. J. W. Hsueh. 1979 FSH induction of functional $\mathrm{LH}$ receptors in granulosa cells cultured in chemically defined medium. Nature (Lond.). 279:336-338.

24. Adashi, E. Y., C. E. Resnick, M. E. Svoboda, and J. J. Van Wyk. 1985 Somatomedin-C enhances induction of luteinizing hormone receptors by follicle stimulating hormone in cultured rat granulosa cells. Endocrinology. 116:2369-2375.

25. Bogovich, K., J. S. Richards, and L. E. Reichert, Jr. 1981. Obligatory role of luteinizing hormone (LH) in the initiation of preovulatory follicular growth in the pregnant rat: specific effects of human chorionic gonadotropin and follicle stimulating hormone on LH receptors and steroidogenesis in theca, granulosa, and luteal cells. Endocrinology. 109:860-867.

26. Eckstein, B., Greenbaum O., and Cohen S. Kinetic studies on ovarian C-17,20 lyase activity: effect of luteinizing hormone surge. Endocrinology. 117:2376-2382.

27. Richards, J. S., and L. Hedin. 1988. Molecular aspects of hormone action in ovarian follicular development, ovulation, and luteinization. 1988. Annu. Rev. Physiol. 50:441-463.

28. Dufau, M. L., C. A. Winters, M. Hattori, D. Aquilano, J. L. S. Baraño, K. Nozu, A. Baukal, and K. J. Catt. 1984. Hormonal regulation of androgen production by the Leydig cell. J. Steroid Biochem. 20:161-173.

29. Bernier, M., P. Chatelain, J. P. Mather, and J. M. Saez. 1986. Regulation of gonadotropin receptors, gonadotropin responsiveness, and cell multiplication by somatomedin-C and insulin in cultured pig Leydig cells. J. Cell. Physiol. 129:257-263.

30. Mondschein, J. S., and D. W. Schomberg. 1981. Growth factors modulate gonadotropin receptor induction in granulosa cell cultures. Science (Wash. DC). 211:1179-1180.

31. Zipf, W. B., A. H. Payne, and R. P. Kelch. 1978. Dissociation of lutropin-induced loss of testicular lutropin receptors and lutropin-induced desensitization of testosterone synthesis. Biochim. Biophys. Acta. 540:330-336. 